\title{
Constraints Faced by Farmers Practicing Organic Farming in Hill Region of Uttarakhand, India
}

\author{
Rifat Haneef $^{1^{*}}$, Gyanendra Sharma ${ }^{1}$ and Taufiq Ahmad ${ }^{2}$ \\ ${ }^{1}$ Department of Agricultural Communication, Govind Ballabh Pant University of Agricultural \\ \& Technology, Pantnagar, Uttarakhand, India \\ ${ }^{2}$ College of Forestry, VCSG Uttarakhand University of Horticulture and Forestry, Ranichauri, \\ Tehri Garhwal, Uttarakhand, India \\ *Corresponding author
}

\begin{abstract}
A B S T R A C T

\begin{tabular}{|l|}
\hline Ke y w or d s \\
Constraints, \\
Organic, Farming, \\
Farmers, Mean \\
score \\
\hline Article Info \\
\hline Accepted: \\
12 April 2019 \\
Available Online: \\
10 May 2019 \\
\hline \hline
\end{tabular}

Many farmers in the country have only vague ideas about organic farming and its advantages as against the conventional farming methods. The present study was carried out in Uttarakhand state. Two districts namely, Rudraprayag from Garhwal region and Nainital from Kumaon region were selected purposively as the locale for the proposed study. In Rudraprayag district one block i.e. Jakholi was selected through simple random sampling and in Nainital district Betalghat block was selected purposively as it is the only block in the district declared as organic. Four villages from each selected block were selected through simple random sampling. From the eight villages, the respondents were selected by using the PPS (Probability Proportional to Size) sampling method. Thus, a total sample of 200 respondents was selected for the purpose of the present study. On the basis of mean score, economic constraints in the order of severity were initial low price for the organic produce (2.89), initial yield loss (2.76), inadequate availability of credit (2.33), higher cost involved in the certification charges (1.97) and inadequate subsidies for organic cultivation of crops (1.88), infrastructural constraints in the order of severity were lack of training institutions (1.93), lack of indigenous certification agencies (1.81) and lack of specialized institutes for doing research on organic farming (1.70).
\end{abstract}

\section{Introduction}

Organic farming involves management of the agro-eco system as autonomous, based on the capacity of the soil in the given local climatic conditions. In spite of the ridicule poured out on organic farming by many, it has come to stay and is spreading steadily but slowly all over the world. India has been very slow to adopt it but it has made Inroads into our conventional farming system. One advantage we have here is the fact that the farming techniques practiced in this country before the advent of the green revolution were basically eco-friendly and they have not faded away from the memories of the present elder generation of our farming community (Narayanan, 2005).

Organic farming seems to be the best alternative to the present system of farming solely depending on the chemicals. Organic 
farming may prove to be a boon to curb these adverse effects. Switching over to organic ways of farming can help the farmers to increase their net incomes and farm employment, besides building self reliance. According to FAO, "Organic farming is defined as a holistic production management system which promotes and enhances agroecosystem health, including biodiversity, biological cycles and soil biological activity". This is accomplished by using on-farm agronomic, biological and mechanical methods, as opposed to using synthetic materials, to fulfill any specific function within the system (FAO, 1999). According to International Federation of Organic Agriculture Movement (IFOAM), goal of organic farming is sustainable production of quality food with little or no effect on the environment.

This goal has not been fully achieved by current agricultural practices i.e. conventional farming. Therefore there is a need to encourage organic farming which is capable of providing solutions to the current agricultural problems and help to achieve optimal production of quality food sustainably (IFOAM, 2007).

There are basically two types of organic farming. Certified organic farming is oriented towards production and focus on few highvalue crops and quality. The agro-organic methods are used in varying degrees according to the guidelines of National Program on Organic Production (NPOP). Certified organic farming gives access to the market and better prices. Certified organic products are exported globally. Noncertified/informal organic farming is an agroecological farming system which is organic by default mainly in drylands or rainfed areas. There is conscious use of organic methods depending on their experience. It follow the principles or ideas of IFOAM but may not be in full compliance with their set standards and it is not necessarily certified and they do not get good prices for their produce.

The promotion of organic farming in India gained momentum from the introduction of National Program for Organic Production (NPOP) which was approved in May 2001 under the Ministry of Commerce. Some Indian organic certification bodies have been accredited under NPOP, the largest being INDOCERT. The Government of India has initiated National Project on Organic Farming (NPOF) in 2004. NPOF is being implemented by National Centre of Organic Farming at Ghaziabad.

According to Gill and Prasad, complete knowledge about organic farming practices and advantages is not filtered to the small farmers, which should be actual target and potential beneficiary of organic farming. Further, whatsoever information reaches to small farmers is very often not backed by scientifically proven results in different farming situations prevailing in Indian subcontinent (Gill and Prasad, 2009).

Keeping all these facts in mind the present investigation "Constraints faced by farmers practicing organic farming in hill region of Uttarakhand" was under taken.

\section{Materials and Methods}

The present study was carried out in Uttarakhand state. Two districts namely, Rudraprayag from Garhwal region and Nainital from Kumaon region were selected purposively as the locale for the proposed study. In Rudraprayag district one block i.e. Jakholi was selected through simple random sampling and in Nainital district Betalghat block was selected purposively as it is the only block in the district declared as organic. Four villages from each selected block were 
selected through simple random sampling. From the eight villages, the respondents were selected by using the PPS (Probability Proportional to Size) sampling method. Thus, a total sample of 200 respondents was selected for the purpose of the present study.

Interview schedule was used as a tool for collecting data in face to face situation. Each and every part of the interview schedule was thoroughly examined and discussed with the advisory committee before giving it a final shape. The interview schedule was validated by experts related to the field.

For the measurements of constraints faced by the farmers involved in organic farming five dimensions of constraints were analyzed through an arbitrary scale developed for the purpose. The arbitrary scale contains a set of twenty three questions in five dimensions viz., economic constraints, infrastructural constraints, technological constraints, situational/environmental constraints and marketing constraints. Responses were obtained on their severity on a three-point continuum ranging from least severe, severe to most severe for all statements with scores of 1, 2 and 3 respectively. These constraints were ranked based on weighted mean score. The tool was pilot tested in the field conditions, on 30 non sample respondents. The necessary modifications, alterations and suggestions were incorporate before conducting the survey.

\section{Results and Discussion}

Data regarding constraints faced by the organic farmers is presented in the Table 1 given below it is observed that the economic constraints were ranked first with the mean score value of 2.36 out of maximum possible score of 3 and hence it was the major constraint faced by the farmers in practicing organic farming. The other constraints in the order of severity were marketing constraints (2.11), technological constraints (1.91), infrastructural constraints (1.81) and situational/environmental constraints (1.56).

Thus it can be concluded that economic constraints and marketing constraints were found to be most severe by the respondents. These are the constraints that inhibit the farmers from pursuing organic farming. Initial low price for the organic produce and lack of specialized markets for organic produce were crucial issues that were faced by the organic farmers. Similar findings were reported by Shinogi (2011) who identified three major constraints in the promotion of organic farming i.e. grading and marketing constraints, certification constraints and economic constraints out of total seven groups of constraints.

Each of the dimensions of constraints mentioned above have been studied and described in detail by describing the specific constraints under each dimension, based on the perception of farmers of severity of constraints to organic farming.

\section{Economic constraints}

Data regarding economic constraints faced by the organic farmers is presented in the Table 2. On the basis of mean score, economic constraints in the order of severity were initial low price for the organic produce (2.89), initial yield loss (2.76), inadequate availability of credit (2.33), higher cost involved in the certification charges (1.97) and inadequate subsidies for organic cultivation of crops (1.88).

Majority of the respondents (89.00 percent) expressed initial low price for the organic produce as the most severe constraint having mean score of 2.89. This is because the farmers suffer from low yield and in addition, 
they don't have certification restricting them from getting premium prices for their produce. Initial yield loss was expressed as most severe constraint by 76.00 percent of respondents and inadequate availability of credit was expressed as severe constraint by 67.00 percent of respondents. The farmers face difficulty in getting credit from any institute and for their credit needs, they mostly depends on the money lenders.

More than half (51.00 percent) respondents expressed higher cost involved in the certification charges as severe constraint. Most of the respondents were not aware of the certification process and they also find it time consuming. Inadequate subsidies for organic cultivation of crops were expressed as least severe by 37.50 percent of respondents. Some of the farmers in the study area got subsidy for setting up of vermi-composting pit but they suffer from lack of technical or practical knowledge related to it (Jangid, 2012). Thimmareddy (2001) reported similar finding that decline in returns in initial period of 3 to 4 years of organic farming was the major constraint expressed by the respondents. Similar findings were also reported by Pathak (2016) that lack of finance was one of the major constraints faced by the respondents.

\section{Infrastructural constraints}

Data regarding infrastructural constraints faced by the organic farmers is presented in the Table 3. On the basis of mean score, infrastructural constraints in the order of severity were lack of training institutions (1.93), lack of indigenous certification agencies (1.81) and lack of specialized institutes for doing research on organic farming (1.70)

Majority of the respondents (40.50 percent) expressed lack of training institutions as the severe constraint having mean score of 1.93 .
Lack of indigenous certification agencies was expressed as severe constraint by 41.50 percent of respondents and lack of specialized institutes for doing research on organic farming was expressed as least severe constraint by 46.50 percent of respondents. Only few of the farmers (35.5 percent) had attended trainings related to the field of agriculture that is because of the lack of training institutions. Farmers wanted to update and upgrade their knowledge on organic farming and learn new methods and techniques related to it.

\section{Technological constraints}

Data regarding technological constraints faced by the organic farmers is presented in the Table 4. On the basis of mean score, technological constraints in the order of severity were inadequate availability or shortage of quality disease free seeds/planting materials (2.18), lack of timely research information about organic farming technologies (1.97), non availability of organic inputs in time (1.82) and lack of standard package of practices for practicing organic farming (1.68).

Majority of the respondents (74.00 percent) expressed inadequate availability or shortage of quality disease free seeds/planting materials as the severe constraint having mean score of 2.18. Lack of timely research information about organic farming technologies was expressed as severe constraint by 49.00 percent of respondents and non availability of organic inputs in time was expressed as least severe constraint by 55.50 percent of respondents. Majority of the respondents (47.00 percent) expressed lack of standard package of practices for practising organic farming as the least severe constraint having mean score of 1.68. Quality seeds were not easily available to the farmers so they mostly used locally available materials. 
Information related to organic farming technologies were not provided timely to farmers may be due to the lack of trainings. Only few farmers had attended trainings and most of them were not exposed to any training related to organic farming. Organic inputs such as farmyard manure were easily available to most farmers as they possess livestock.

\section{Situational/Environmental constraints}

Data regarding situational/environmental constraints faced by the organic farmers is presented in the Table 5. On the basis of mean score, situational/environmental constraints in the order of severity were erratic onset of monsoon rain (2.11), heavy incidence of pests and diseases (1.98), requirement of long period to get positive responses from the ecosystem (1.12) and non availability of labour (1.05).

Majority of the respondents (43.50 percent) expressed erratic onset of monsoon rain as the most severe constraint having mean score of 2.11. Heavy incidence of pests and diseases was expressed as severe constraint by 86.50 percent of respondents and requirement of long period to get positive responses from the ecosystem was expressed as least severe constraint by 89.00 percent of respondents. Majority of the respondents (95.00 percent) expressed non availability of labour as the least severe constraint having mean score of 1.05 .

Farmers reported that the yield suffer from hail storm during rainfall. Besides pests and diseases, farmers also complained about wild animals (wild boars and monkeys) that destroy their crops. Since the farmers had been practicing organic farming by default, so they do not have to wait long to get positive responses from the ecosystem. Most farmers and their family members work themselves on their fields and only few of them were working as labourers on others field. Mayowa and Meludu (2014) reported similar findings that pest and disease infestation was the second most severe constraints faced by respondents. The above findings are contradictory to the findings of Jaganathan et al., (2015) who reported that majority of respondents expressed the problem of nonavailability of labour.

\section{Marketing constraints}

Data regarding marketing constraints faced by the organic farmers is presented in the Table 6. On the basis of mean score, marketing constraints in the order of severity were lack of specialized markets for organic produce (2.78), high transportation cost (2.74), lack of reliable market information, regulation and distribution channels (2.63), lack of farming cooperatives for marketing (2.15), interference of middlemen in the market (1.99), lack of awareness about grading and different grades (1.27) and lack of storage facilities (1.25).

Majority of the respondents (79.00 percent) expressed lack of specialized markets for organic produce as the most severe constraint having mean score of 2.78. High transportation cost and lack of reliable market information, regulation and distribution channels were expressed as most severe constraints by 75.000 percent and 63.00 percent of respondents respectively. Lack of farming cooperatives for marketing and interference of middlemen in the market were expressed as severe constraints by 77.000 percent and 78.00 percent of respondents respectively. Majority of the respondents expressed lack of awareness about grading and different grades (76.00 percent) and lack of storage facilities (80.00 percent) as the least severe constraints. Thimmareddy (2001) also reported same finding that major 
constraint faced by the farmers was no separate market for organically grown produce. Farmers reported that the yield suffer from hail storm during rainfall.

Table.1 Constraints faced by the farmers in practicing organic farming $(n=200)$

\begin{tabular}{|c|c|c|c|c|}
\hline S. No. & Constraints & Mean score & $\begin{array}{l}\text { Total } \\
\text { mean } \\
\text { score }\end{array}$ & Rank \\
\hline \multirow[t]{6}{*}{1.} & \multicolumn{2}{|l|}{ Economic constraints } & \multirow{6}{*}{2.36} & \multirow{6}{*}{ I } \\
\hline & a. Inadequate availability of credit & 2.33 & & \\
\hline & $\begin{array}{l}\text { b. Inadequate subsidies for organic cultivation of } \\
\text { crops }\end{array}$ & 1.88 & & \\
\hline & c. Initial yield loss & 2.76 & & \\
\hline & d. Initial low price for the organic produce & 2.89 & & \\
\hline & e. Higher cost involved in the certification charges & 1.97 & & \\
\hline \multirow[t]{4}{*}{2.} & \multicolumn{2}{|l|}{ Infrastructural constraints } & \multirow{4}{*}{1.81} & \multirow{4}{*}{ IV } \\
\hline & a. Lack of training institutions & 1.93 & & \\
\hline & b. Lack of indigenous certification agencies & 1.81 & & \\
\hline & $\begin{array}{l}\text { c. Lack of specialized institutes for doing research } \\
\text { on organic farming }\end{array}$ & 1.7 & & \\
\hline \multirow[t]{5}{*}{3.} & \multicolumn{2}{|l|}{ Technological constraints } & \multirow{5}{*}{1.91} & \multirow{5}{*}{ III } \\
\hline & $\begin{array}{l}\text { a. Lack of timely research information about } \\
\text { organic farming technologies }\end{array}$ & 1.97 & & \\
\hline & $\begin{array}{l}\text { b. Inadequate availability or shortage of quality } \\
\text { disease free seeds/planting materials }\end{array}$ & 2.18 & & \\
\hline & c. Non availability of organic inputs in time & 1.82 & & \\
\hline & $\begin{array}{l}\text { d. Lack of standard package of practices for } \\
\text { practising organic farming }\end{array}$ & 1.68 & & \\
\hline \multirow[t]{5}{*}{4.} & Situational/environmental constraints & & \multirow{5}{*}{1.56} & \multirow{5}{*}{$\mathrm{V}$} \\
\hline & a. Non availability of labour & 1.05 & & \\
\hline & b. Heavy incidence of pests and diseases & 1.98 & & \\
\hline & $\begin{array}{l}\text { c. Requirement of long period to get positive } \\
\text { responses from the ecosystem }\end{array}$ & 1.12 & & \\
\hline & d. Erratic onset of monsoon rain & 2.11 & & \\
\hline \multirow[t]{8}{*}{5.} & Marketing constraints & & \multirow{8}{*}{2.11} & \multirow{8}{*}{ II } \\
\hline & $\begin{array}{l}\text { a. Lack of reliable market information, regulation } \\
\text { and distribution channels }\end{array}$ & 2.63 & & \\
\hline & b. High transportation cost & 2.74 & & \\
\hline & $\begin{array}{l}\text { c. Lack of specialized markets for organic } \\
\text { produce }\end{array}$ & 2.78 & & \\
\hline & d. Lack of farming cooperatives for marketing & 2.15 & & \\
\hline & e. Interference of middlemen in the market & 1.99 & & \\
\hline & $\begin{array}{l}\text { f. Lack of awareness about grading and different } \\
\text { grades }\end{array}$ & 1.27 & & \\
\hline & g. Lack of storage facilities & 1.25 & & \\
\hline
\end{tabular}


Table.2 Economic constraints faced by the farmers in practicing organic farming $(\mathrm{n}=200)$

\begin{tabular}{|c|c|c|c|c|c|c|c|c|c|}
\hline \multirow[t]{2}{*}{ S. No. } & \multirow[t]{2}{*}{ Economic constraints } & \multicolumn{2}{|c|}{ Most severe } & \multicolumn{2}{|c|}{ Severe } & \multicolumn{2}{|c|}{ Least severe } & \multirow[t]{2}{*}{ Mean score } & \multirow[t]{2}{*}{ Rank } \\
\hline & & f & $\%$ & $\mathbf{f}$ & $\%$ & f & $\%$ & & \\
\hline 1. & Inadequate availability of credit & 66 & 33.00 & 134 & 67.00 & 0 & 0 & 2.33 & III \\
\hline 2. & $\begin{array}{l}\text { Inadequate subsidies for organic } \\
\text { cultivation of crops }\end{array}$ & 51 & 25.50 & 74 & 37.00 & 75 & 37.50 & 1.88 & $\mathrm{~V}$ \\
\hline 3. & Initial yield loss & 152 & 76.00 & 48 & 24.00 & 0 & 0 & 2.76 & II \\
\hline 4. & $\begin{array}{l}\text { Initial low price for the organic } \\
\text { produce }\end{array}$ & 178 & 89.00 & 22 & 11.00 & 0 & 0 & 2.89 & I \\
\hline 5. & $\begin{array}{l}\text { Higher cost involved in the } \\
\text { certification charges }\end{array}$ & 46 & 23.00 & 102 & 51.00 & 52 & 26 & 1.97 & IV \\
\hline
\end{tabular}

Table. 3 Infrastructural constraints faced by the farmers in practicing organic farming $(n=200)$

\begin{tabular}{|c|c|c|c|c|c|c|c|c|c|}
\hline \multirow[t]{2}{*}{ S. No. } & \multirow[t]{2}{*}{ Infrastructural constraints } & \multicolumn{2}{|c|}{ Most severe } & \multicolumn{2}{|c|}{ Severe } & \multicolumn{2}{|c|}{ Least severe } & \multirow{2}{*}{$\begin{array}{l}\text { Mean } \\
\text { score }\end{array}$} & \multirow[t]{2}{*}{ Rank } \\
\hline & & $\mathbf{f}$ & $\%$ & f & $\%$ & f & $\%$ & & \\
\hline 1. & Lack of training institutions & 52 & 26.00 & 81 & 40.50 & 67 & 33.50 & 1.93 & I \\
\hline 2. & $\begin{array}{l}\text { Lack of indigenous certification } \\
\text { agencies }\end{array}$ & 40 & 20.00 & 83 & 41.50 & 77 & 38.50 & 1.81 & II \\
\hline 3. & $\begin{array}{l}\text { Lack of specialized institutes for } \\
\text { doing research on organic farming }\end{array}$ & 33 & 16.50 & 74 & 37.00 & 93 & 46.50 & 1.70 & III \\
\hline
\end{tabular}

Table.4 Technological constraints faced by the farmers in practicing organic farming $(n=200)$

\begin{tabular}{|c|c|c|c|c|c|c|c|c|c|}
\hline \multirow[t]{2}{*}{ S. No. } & \multirow[t]{2}{*}{ Technological constraints } & \multicolumn{2}{|c|}{ Most severe } & \multicolumn{2}{|c|}{ Severe } & \multicolumn{2}{|c|}{$\begin{array}{l}\text { Least } \\
\text { severe }\end{array}$} & \multirow[t]{2}{*}{ Mean score } & \multirow[t]{2}{*}{ Rank } \\
\hline & & f & $\%$ & f & $\%$ & f & $\%$ & & \\
\hline 1. & $\begin{array}{l}\text { Lack of timely research information } \\
\text { about organic farming technologies }\end{array}$ & 48 & 24.00 & 98 & 49.00 & 54 & 27.00 & 1.97 & II \\
\hline 2. & $\begin{array}{l}\text { Inadequate availability or shortage of } \\
\text { quality disease free seeds/planting } \\
\text { materials }\end{array}$ & 44 & 22.00 & 148 & 74.00 & 8 & 4.00 & 2.18 & I \\
\hline 3. & $\begin{array}{l}\text { Non availability of organic inputs in } \\
\text { time }\end{array}$ & 55 & 27.5 & 34 & 17.00 & 111 & 55.50 & 1.82 & III \\
\hline 4. & $\begin{array}{l}\text { Lack of standard package of } \\
\text { practices for practising organic } \\
\text { farming }\end{array}$ & 30 & 15.00 & 76 & 38.00 & 94 & 47.00 & 1.68 & IV \\
\hline
\end{tabular}

Table.5 Situational/Environmental constraints faced by the farmers in practicing organic farming $(n=200)$

\begin{tabular}{|c|c|c|c|c|c|c|c|c|c|}
\hline \multirow{2}{*}{$\begin{array}{l}\text { S. } \\
\text { No. }\end{array}$} & \multirow{2}{*}{$\begin{array}{c}\text { Situational/Environmental } \\
\text { constraints }\end{array}$} & \multicolumn{2}{|c|}{ Most severe } & \multicolumn{2}{|c|}{ Severe } & \multicolumn{2}{|c|}{ Least severe } & \multirow{2}{*}{$\begin{array}{l}\text { Mean } \\
\text { score }\end{array}$} & \multirow[t]{2}{*}{ Rank } \\
\hline & & f & $\%$ & f & $\%$ & f & $\%$ & & \\
\hline 1. & Non availability of labour & 0 & 0 & 10 & 5.00 & 190 & 95.00 & 1.05 & IV \\
\hline 2. & Heavy incidence of pests and diseases & 12 & 6.00 & 173 & 86.50 & 15 & 7.50 & 1.98 & II \\
\hline 3. & $\begin{array}{l}\text { Requirement of long period to get } \\
\text { positive responses from the ecosystem }\end{array}$ & 3 & 1.50 & 19 & 9.50 & 178 & 89.00 & 1.12 & III \\
\hline 4. & Erratic onset of monsoon rain & 87 & 43.50 & 49 & 24.50 & 64 & 32.00 & 2.11 & I \\
\hline
\end{tabular}


Table.6 Marketing constraints faced by the farmers in practicing organic farming $(n=200)$

\begin{tabular}{|c|c|c|c|c|c|c|c|c|c|}
\hline \multirow[t]{2}{*}{ S. No. } & \multirow[t]{2}{*}{ Marketing constraints } & \multicolumn{2}{|c|}{ Most severe } & \multicolumn{2}{|c|}{ Severe } & \multicolumn{2}{|c|}{$\begin{array}{l}\text { Least } \\
\text { severe }\end{array}$} & \multirow[t]{2}{*}{$\begin{array}{l}\text { Mean } \\
\text { score }\end{array}$} & \multirow[t]{2}{*}{ Rank } \\
\hline & & f & $\%$ & f & $\%$ & f & $\%$ & & \\
\hline 1. & $\begin{array}{l}\text { Lack of reliable market } \\
\text { information, regulation and } \\
\text { distribution channels }\end{array}$ & 126 & 63.00 & 74 & 37.00 & 0 & 0 & 2.63 & III \\
\hline 2. & High transportation cost & 150 & 75.00 & 48 & 24.00 & 2 & 1.00 & 2.74 & II \\
\hline 3. & $\begin{array}{l}\text { Lack of specialized markets } \\
\text { for organic produce }\end{array}$ & 158 & 79.00 & 40 & 20.00 & 2 & 1.00 & 2.78 & I \\
\hline 4. & $\begin{array}{l}\text { Lack of farming cooperatives } \\
\text { for marketing }\end{array}$ & 38 & 10.00 & 154 & 77.00 & 8 & 4.00 & 2.15 & IV \\
\hline 5. & $\begin{array}{l}\text { Interference of middlemen in } \\
\text { the market }\end{array}$ & 21 & 10.50 & 156 & 78.00 & 23 & 11.5 & 1.99 & V \\
\hline 6. & $\begin{array}{l}\text { Lack of awareness about } \\
\text { grading and different grades }\end{array}$ & 7 & 3.50 & 41 & 20.5 & 152 & 76.00 & 1.27 & VI \\
\hline 7. & Lack of storage facilities & 10 & 5.00 & 30 & 15.00 & 160 & 80.00 & 1.25 & VII \\
\hline
\end{tabular}

In conclusion, the growth of organic farming in India is relatively slower despite the fact that it is the best solution to the environmental problems such as climate change, health and sustainability issues that India is facing today due to conventional farming. In hill regions, small farm holders face a number of constraints in practicing organic farming. The major constraints faced by them were economic and marketing including initial low price for the organic produce, lack of specialised market, initial yield loss and high transportation cost. These constraints need to be overcome by appropriate interventions. Extension services of the state should be strong and information on different aspects of organic farming should be provided to the farmers.

\section{References}

Gill, M.S., and Prasad Kamta 2009. Organic Agriculture-Concept, Status and Strategies in Indian Perspective. Compendium on Advances in Organic Farming, Project Directorate for Farming System Research, ICAR,
Modipuram. pp. 1-7.

International Federation of Organic Agriculture Movement (IFOAM). 2007. Africa Organic, IFOAM newsletter, 1(7).

Jaganathan, D., Bahal, R., Burman, R.R. and Lenin, V. 2012. Knowledge Level of Farmers on Organic Farming in Tamil Nadu. Indian Research Journal of Extension Education. 12(3).

Jangid, M. K., Khan I. M. and Singh, S.2012. Constraints Faced by the Organic and Conventional Farmers in Adoption of Organic Farming Practices, Indian Research Journal of Extension Education, Special Issue (Volume II), 2012

Mayowa, O and Meludu, Y.2014. Need assessment of women vegetable farmers on ecological organic agriculture (EOA) in Nigeria. In Rahmann $G$ and Aksoy U (Eds.) Proceedings of the fourth ISOFAR Scientific Conference. 'Building Organic Bridges', at the Organic World Congress 2014, 13-14 0ctober, Istanbul, Turkey (e-print ID 23909). 
Narayanan, S. 2005. Organic Farming In India: Relevance, Problems and Constraints Occasional Paper - 38 https://www.nabard.org/demo/auth/wr itereaddata/File/OC\%2038.pdf

Pathak, R. 2016. A Study on Knowledge and Adoption Behaviour of Farmers using Bio fertilizers in Ujjain District (Madhya Pradesh). Unpublished M.Sc. Thesis. Department of Extension Education and Rural Sociology, College of Agriculture, Rajmata Vijayaraje Scindia Krishi
Vishwa Vidyalaya, Indore (M.P.). Shinogi K. C. 2011. Organic Farming In Kerala: An Assessment of Adoption, Sustainability And Constraints. Unpublished M.Sc. Thesis. Indian Agricultural Research Institute. Retrieved from http://krishikosh. egranth.ac.in/bitstream/1/88541/1/Shi noji\%20Thesis\%20Full.pdf

Thimmareddy, K.S. 2001. Case studies on Organic farming. M.Sc. (Agri.) Thesis. University of Agricultural Sciences, Dharwad, Karnataka (India).

\section{How to cite this article:}

Rifat Haneef, Gyanendra Sharma and Taufiq Ahmad. 2019. Constraints Faced by Farmers Practicing Organic Farming in Hill Region of Uttarakhand, India. Int.J.Curr.Microbiol.App.Sci. 8(05): 1149-1157. doi: https://doi.org/10.20546/ijcmas.2019.805.130 